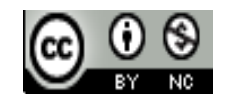

Journal of Education, Teaching, and Learning is licensed under

A Creative Commons Attribution-NonCommercial 4.0 International License.

\title{
TAXonomy of Educational Problems in SuPPORT OF READINESS FOR THE IMPLEMENTATION OF MINIMUM COMPETENCY ASSESSMENT AND CHARACTER SURVEY IN ELEMENTARY SCHOOLS
}

\author{
Aunurrahman \\ Universitas Tanjungpura, Pontianak, Indonesia \\ E-mail:aunurrahman@fkip.untan.ac.id
}

\begin{abstract}
This study aims to determine the essential dimensions of primary school education problems in Sintang district based on their types and aspects to analyze the readiness to implement the minimum competency assessment and character survey in 2021 with a focus on two main study dimensions, namely the main problems of education and the dimensions of readiness to implement the minimum competency assessment policy and character survey. The data was collected by combining qualitative and quantitative approaches through the implementation of a Focus Group Discussion (FGD) and a questionnaire. The FGD was attended by supervisors, school principals and elementary school teachers. Meanwhile, the questionnaire was filled in by elementary school teachers who were spread over some elementary schools in several sub-districts of Sintang district. Qualitative data analysis used taxonomic analysis techniques (taxonomy analysis) and interactive analysis from Miles and Huberman. Meanwhile, the quantitative analysis uses descriptive statistical analysis. The results showed that the taxonomy of educational problems in supporting the readiness to implement the minimum competency assessment and character survey in elementary schools in Sintang district was seen from the teacher dimensions regarding shortages and uneven distribution. In the curriculum dimension, it is considered that changes are too fast so that it becomes a source of confusion for some teachers, and in the learning process that has not made good use of information and communication technology tools. In the leadership and management dimension, the implementation of discipline and transparency is still low. In the dimension of school readiness towards implementing minimum competency assessment policies and character surveys in 2021, especially concerning the principal who not yet optimal initiative to encourage teacher involvement to find out and explore new policies and less proactive teachers in seeking information or increasing knowledge related to minimum competency assessment policies and character surveys through various available sources of information.
\end{abstract}

Keywords: Taxonomy of Educational Issues; Assessment of Minimum Competencies; Character Survey

\section{INTRODUCTION}

The achievement of the quality of education following the established standards is an important indicator in assessing the progress of the development of a nation or a region. This is mainly because education is the main pillar in preparing human resources as actors and supporters of development. The urge to continue to find innovative ways to achieve the acceleration of the quality of education in Indonesia is indeed reasonable because even though it is acknowledged that it has made progress, it is seen from the service indicators that it is still far from the expected target, let alone compared to other countries. Research conducted by Widodo (2015) revealed several cases that illustrate this condition including, that (a) $75 \%$ of education services in Indonesia do not meet minimum service standards, (b) equitable access and quality of education in Indonesia in 2013-2014 which shows that Indonesia is ranked 40 out of 40 countries, (c) for higher education in Indonesia is ranked 49 out of 50 countries, (d) for literacy skills in science and math mapping shows that Indonesian children are in position 40 out of 42 countries. However, in a broad dimension, there have been significant advances that have been made compared to previous times. Quantitatively, education in Indonesia has progressed. The indicator of achievement can be seen in the literacy of the community, which reached $67.24 \%$. This is as a result of the education equality program, especially through the SD IMPRES built by the New Order. However, success in terms of qualitative education in Indonesia has not succeeded in building a smart and creative national character let alone superior (Afifah, 2015:5). 
Since education is recognized as the main force for providing competent and quality human resources, the policy to give priority to this sector must be clear. Nasution (2015: 7) stated that modern quality systems are characterized by active participation in the continuous quality improvement process. If quality is delegated to the quality control department only, then everyone will have the perception that quality is not a key concern.

Among the policies of the Minister of Education and Culture of the Republic of Indonesia which are directed at making educational changes that have received great attention among various parties related to education providers at the school level is the decision to replace the National Examination with a minimum competency assessment and character survey starting in 2021. Based on various available source, the government has designed and tested this system. Through the explanation of the Head of the Ministry of Education and Culture's Research and Development Agency, it was stated that this method had been designed and tested. Minimum competency assessment or also known as Indonesian Student Competency Assessment or ASI (Yanuar, 2019). The benchmark for this method is the Program for International Student Assessment (PISA) and Trends in International Mathematics and Science Study (TIMSS) assessment method. "The minimum competency assessment is a minimum competency where we can map schools and regions based on minimum competencies. Minimum Competency Assessment (AKM) is an assessment of the basic competencies needed by all students to be able to develop their capacities and participate positively. There are two basic competencies measured by AKM, namely reading literacy and mathematical literacy (numeracy). AKM is intended to measure competence in-depth, not just mastery of content (Mendikbud, 2020: 1). The material has only two cognitive parts, the first is literacy and the second is numeration (Mendikbud, 2019).

In addition to the minimum competency assessment, the Minister of Education and Culture will also apply the character survey concept. This character survey is used to determine the character of children at school. The character survey is essentially directed to find out the whole school ecosystem. The realization of the school ecosystem, which is reflected in the development of a good school culture through the application of this character survey, in addition to creating good student character individually, the relationship between school personnel as a whole will be better. The correct character education that is implemented in every school and student and all school members will be able to build a school climate that reflects a positive culture for the continuity of the educational institution. With a good school culture from the results of research conducted by Opata, Alfred \& Stephen (2017: 59), besides being able to improve relationships between school personnel, it is also able to encourage good competition to grow. Besides, good school culture is one of the factors that can encourage the development of teacher professionalism.

In addition to the positive impact of the application of character education that is developed properly, it is also proven to have fostered very positive dimensions of individual development, the experimental results of research conducted by Maunah (2015: 94), proved to have a positive impact on students on several things; (1) growing motivation to be better, (2) not lying, (3) respect for parents and loving others, (4) above something that is accepted, (4) respect for others, (5) increasingly able to appreciate the results cooperation, train leadership, (7) accustomed to the environment and (8) accustomed to helping fellow friends.

This research was conducted in the elementary school of Sintang district, by taking several representative districts to study educational problems in schools by grouping or sorting them based on essential aspects or taxonomically so that it is easier to understand the main problems faced to see the relationship between the readiness to implement the minimum competency assessment and character survey as previously described in a broader perspective, to be able to realize the expectations of development in the regions, of course, it must be preceded by careful analysis and study of social problems in the regions, so that it will produce concrete and specific data or information to formulate the right strategy in improving quality of education on an ongoing basis, and particularly implementing the character assessment and survey.

Sintang District is one of the districts that have a supporting power in the aspect of education both at the provincial and central levels which has a fairly large area. The development of Sintang District Education in a period of five years is directed towards realizing the vision of Sintang District for 2016-2021, namely the realization of a smart, healthy, advanced, religious and prosperous Sintang community supported by the implementation of good and clean governance in 2021 (Pemerintah Kabupaten Sintang, 2016). Various programs which are proclaimed by the central government, of course, must synergize with the successes (milestones) at the regional level at the provincial, city and district levels. The benchmarks for success are on how to embody various strategic policies in the field of education both during the planning, implementation and evaluation processes that are sustainable following existing regional conditions (existing conditions) to achieve the ideal conditions (excepted conditions).

To support the realization of the implementation of the Minimum Competency Assessment or the Indonesian Student Ability Assessment (AKSI) in 2021 as determined in the policy of the Minister of Education and Culture of the Republic of Indonesia, the study of educational issues is considered very important so that it is known which dimensions have good readiness, and dimensions which the dimensions need greater structuring support so that when the policy is implemented it can run smoothly. In other words, quality improvement policies must begin with a concrete and specific understanding of the main problems faced in this field of education. The clearer the problems faced, the easier it will be to determine steps and strategies to push towards the expected progress. If the government has a clear development direction from the real problems faced, it will increasingly be able to realize the progress of society and the region as a whole, because development steps will be arranged 
appropriately so that it can answer every problem faced according to the reality and characteristics occur. The aim of this study to determine the essential dimensions of primary school education problems in Sintang district based on their types and aspects to analyze the readiness to implement the minimum competency assessment and character survey in 2021 with a focus on two main study dimensions, namely the main problems of education and the dimensions of readiness to implement the minimum competency assessment policy and character survey.

\section{Methodology}

To obtain data or information following the objectives of this study, this study used a qualitative research approach. Mc Millan and Schumacher (2001: 398) in an in-depth discussion of the qualitative approach revealed that qualitative research is based on the assumption that reality is multiple, interacting with each other and in which there is an exchange of social experiences interpreted by individuals. This approach that sees things as they are in an interconnected unit is also called a naturalistic inquiry. Through a qualitative data approach and information are described in detail and in-depth. The qualitative approach in this study emphasizes the data collection process through interviews with principals and teachers. Apart from the qualitative approach, this research also uses a quantitative approach, especially to look at aspects that are related to the frequency or intensity of data or information studied. It is important to realize that the use of various triangulation methods reflects an attempt to gain a deep understanding of a phenomenon that is being studied.

\section{A. Research Steps}

As previously explained, this research will describe educational problems based on the types and aspects of elementary schools in Sintang district with a focus on deepening several primary schools representing Sintang district to analyze the readiness to implement the minimum competency assessment and character survey in 2021.

To achieve this goal, the following research steps were carried out:

1. Identifying and analyzing data or information from documents or previous research findings regarding the state of education at elementary schools in Sintang district.

2. Conduct FGD with supervisors, school principals and teachers

3. Perform data analysis and formulate conclusions.

The steps to achieve the research results are as outlined in Fig. 1.

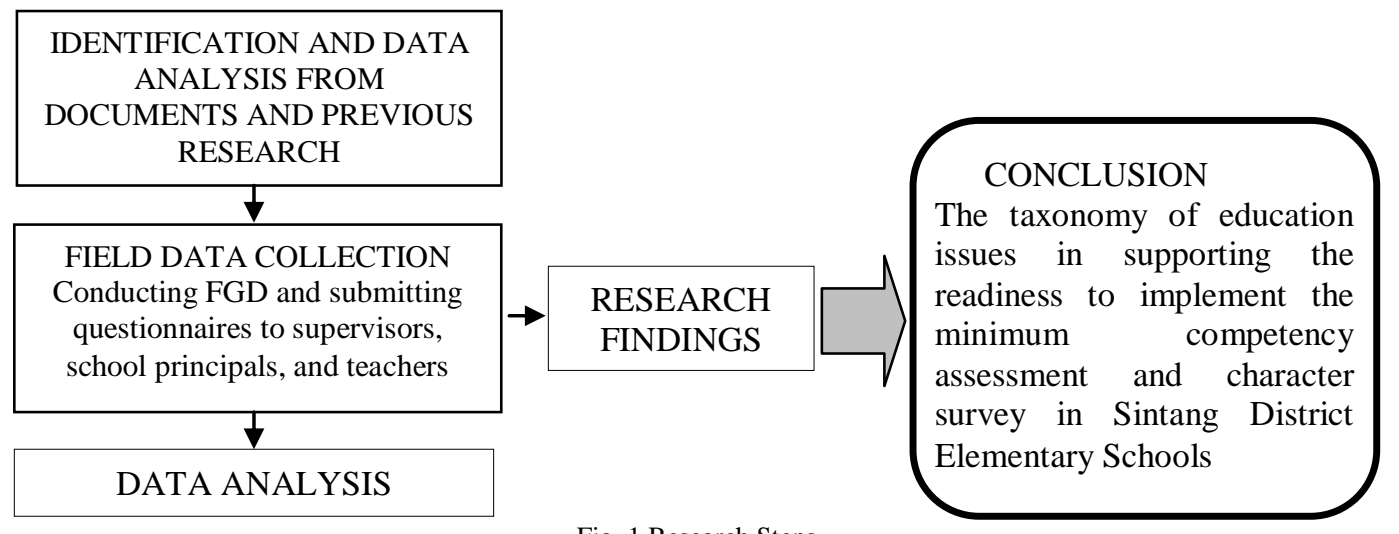

Fig. 1 Research Steps

\section{B. Research Subjects}

It has been stated previously that this research was carried out at elementary schools in Sintang district. To obtain the expected information, the subjects of this study consist of:

1. Principal

2. Primary School Supervisor

3. Elementary School Teachers

\section{Collection Techniques and Tools}

Data collection in this study used data collection techniques through focus group discussions (FGD) and questionnaires. The FGD was attended by elements of supervisors, school principals and teachers. Specifically, the questionnaire was given to 35 elementary school teachers spread across several elementary schools in several sub-districts of Sintang district.

\section{Data Analysis Techniques}

The data obtained through the FGD in the form of qualitative data were analyzed qualitatively using Spradley's Technical Analysis of Taxonomy and Interactive Data Analysis Techniques from Miles and Huberman.

\section{RESULTS AND DISCUSSION}

\section{A. Results}

The presentation of the results of this study is focused on two main dimensions, namely the taxonomy of education problems and the dimensions of the readiness to implement the minimum competency assessment and character survey in elementary schools in Sintang district. 


\section{1) Taxonomy of Educational Problems in Elementary Schools in Sintang District}

Based on the analysis of qualitative data which shows that the problem of education in primary schools in Sintang District in implementing the minimum competency assessment and character survey has quite broad and varied specifications that can be categorized taxonomically.

In the teacher dimension, the main problem faced is the lack of teachers and the lack of equal distribution of placement. The accumulation of teachers generally occurs in schools in the city and suburbs of districts and sub-districts, while in remote and border areas experiencing a shortage of teachers, there are even several primary schools that experience very serious shortages. Another main problem is the low access to opportunities to participate in qualification programs, especially for elementary school teachers. Difficulty in gaining access to information regarding teacher certification is also a major problem faced by teachers, especially for religion teachers in elementary schools. Most teachers also find it difficult to fulfil the demand for certification if the treatment is equalized to schools in more developed regions or regions. Another problem is that most of the teachers still do not master information and communication technology (ICT) in the learning process, some teachers lack the ability and skills in designing learning both in terms of media and learning tools.

In the student dimension, the specific problem is the lack of interest in reading and numeracy literacy, low motivation to learn, moreover, there is a lack of a strong desire to compete to achieve optimal learning outcomes. In other aspects, communication skills are classified as still low, and they are not able to take advantage of learning resources other than the learning resources provided by teachers.

In the leadership and management dimension, principals are aware of special problems, namely that there are still some school principals who are rarely in their assignment, some of them lack transparency in the management of School Operational Assistance (BOS) funds, are less firm in leading, rarely hold coordination meetings with teachers, are less capable cooperating with agencies in the regions such as cooperation with the Puskesmas for palm oil companies and other agencies.

In the dimension of curriculum and learning, special problems are found, especially there are still many teachers who feel confused about the curriculum due to frequent curriculum changes. Besides, there are too many administrative components that must be updated every year and there are many teachers who still use the KTSP curriculum even though they are now using the 2013 curriculum. In the learning aspect, it is still quite a lot dominated by learning with a lecture approach, not using technology-based learning media, so that there are quite a lot of complaints against students who often do not focus on learning.

In the dimension of education/learning facilities, it is known that adequate facilities are still lacking, especially if they are aligned with the demands of technological development and the development of the students themselves.
Likewise, there is still a lack of school rehabilitation in several elementary schools in Sintang District.

In the dimension of community and government support in Sintang District, there are still some people who do not care about school development and there are parents who completely surrender their children to the school and feel that school seems to be the main responsibility for their children's education. Besides, some people lack coordination with the school, so that sometimes it creates misunderstandings. Specifically, for government involvement, namely the lack of attention to schools that are remote or borderline Sintang District.

\section{2) Readiness to Implement Minimum Competency Assessment Policies and Character Surveys}

In addition to examining and exploring educational problems categorized on several dimensions as previously stated, this research is also directed at examining specifically and in more depth information about school readiness in implementing minimum competency assessments and character surveys as policies to be implemented in 2021.

The dimensions of the readiness of the ability to handle learning and student guidance. Concerning this component, the results obtained were as many as 19 teachers stated that the learning process had generally been going smoothly even if there were obstacles that could be overcome, 1 teacher stated that it was very smooth, but there were 15 teachers who stated that it was not smooth and there were many obstacles that could not be overcome. Meanwhile, concerning the handling of student problems, 25 teachers stated that it was going well and all problems were resolved, 2 teachers stated that it was going very well, but 8 teachers experienced student problems that could not be resolved. For more details, the data is presented in Fig. 2.

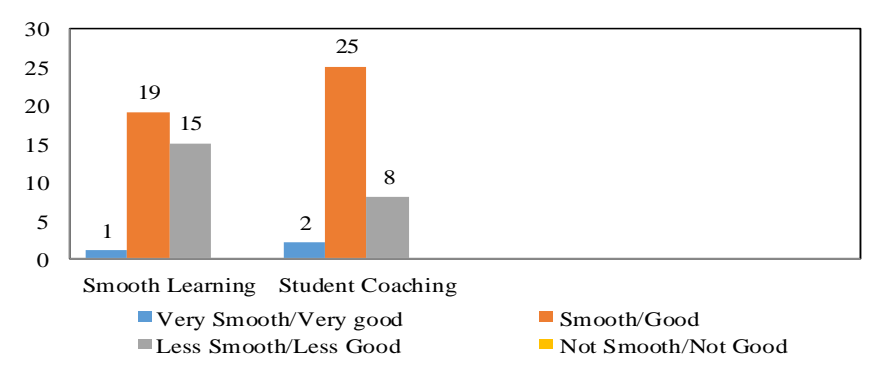

Fig. 2 Readiness for Learning Implementation and Handling of Student Problems

Dimensions of readiness for coordination of new policies. Concerning this aspect, as many as 22 teachers stated that they were always immediately coordinated and conveyed if there were new policies and information, 8 teachers stated that sometimes it was delivered immediately, sometimes it was a bit late and 2 teachers stated that most of the coordination and delivery of new information was delayed and 3 the teacher stated that there was no proper coordination. Meanwhile, concerning the actions to be taken if there is a new policy that is not too clear, according to 17 teachers stated that they immediately carried out discussions and the interior together which was initiated to the school, 13 teachers informed them 
to carry out discussions and deepening after a further explanation from the Education Office, 2 teachers stated that the principal encouraged each teacher to do the deepening independently and there were 3 teachers who stated that they were waiting until there was an explanation/order to implement it. For more details, the data is presented in Fig. 3.

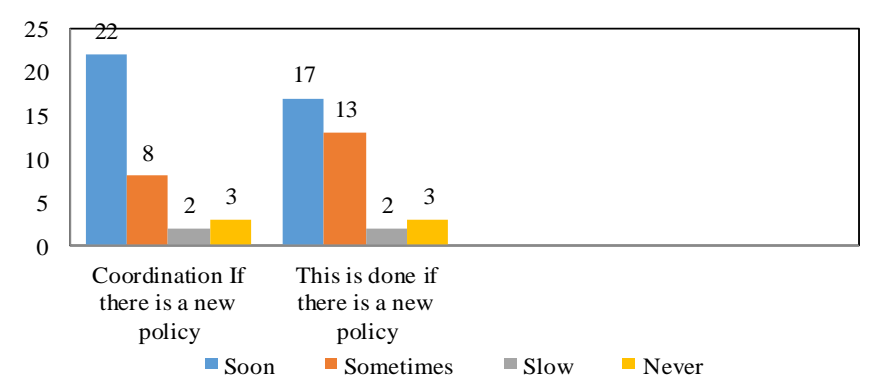

Fig. 3 Readiness for Coordination of New Policies

Dimensions of the readiness of character building students. Concerning care in the development of student character, data obtained from 19 teachers stated that they were quite concerned about developing student character, and 16 teachers stated that they cared. Concerning the suitability of the student character development approach, 23 teachers stated that they were quite appropriate regarding the approaches and methods of character education implemented in schools so far, 7 teachers stated that they were very suitable and 5 teachers said they were not suitable. Concerning the character education approach, 31 teachers stated that through habituation/training related to giving examples and exemplary from teachers, 7 teachers thought it was done through lectures/explanations and 5 teachers stated through orders, admonitions and punishments. For more details, the data is presented in Fig. 4.

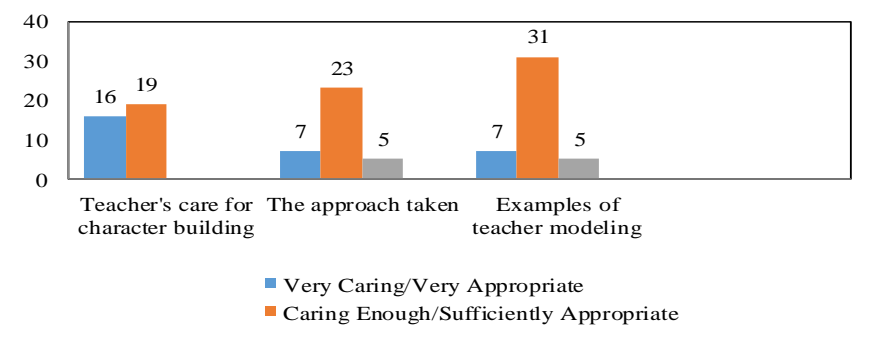

Fig. 4 Readiness for Student Character Development

Dimensions of readiness to follow up on new policies. Concerning the activeness of teachers in seeking information related to new policies, 21 teachers stated that they were always actively seeking and following information and 14 teachers argued that they were sometimes actively seeking and the following information. While concerning attitudes to understanding or studying new policies that are well understood, 24 teachers stated that they are always actively involved in learning related to new policies regarding if there is a special new policy related to teacher duties while the teacher does not have the knowledge and skills related to the task and there were 11 teachers who answered that sometimes they were actively involved. For more details, the data is presented in Fig. 5.

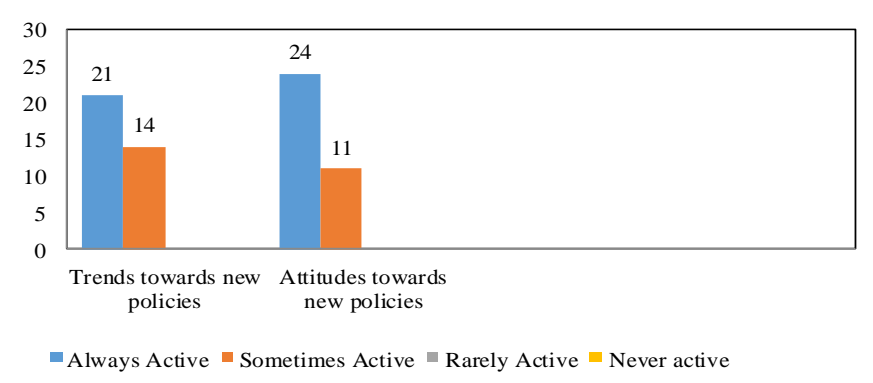

Fig. 5 Readiness to Follow Up on New Policies

The dimensions of knowledge readiness regarding minimum competency assessment policies and character surveys. Concerning information or knowledge related to the minimum competency assessment policy and character survey, from the data obtained, 21 teachers stated that they had never heard or read, as many as 14 people stated that they had read about the assessment policy. Whereas the responses or assessments of teachers regarding the policy plan, 10 teachers thought that the minimum competency assessment policies and character surveys were appropriate or appropriate, 2 teachers stated that they were very appropriate and 2 teachers thought they were not right or not. For more details, the data is presented in Fig. 6.

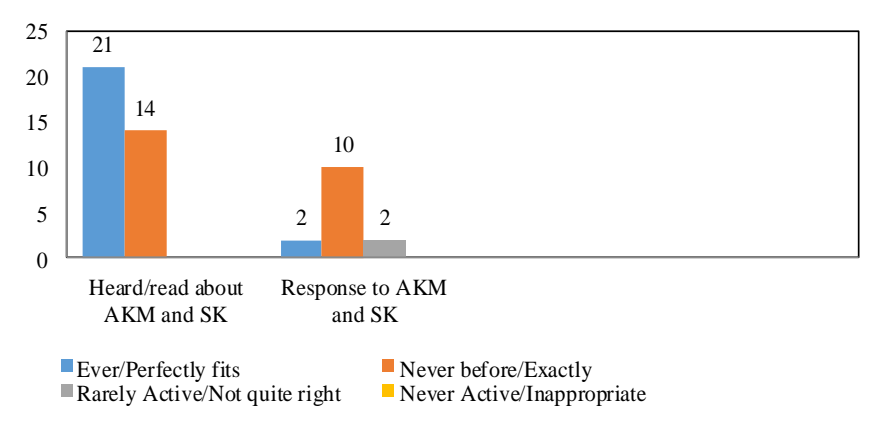

Fig. 6 Knowledge Readiness about AKM Policy and Character Survey

\section{B. Discussion}

The qualitative and quantitative data exposures above provide an overview of the considerable number of educational problems in elementary schools in Sintang district that must be addressed, one of which is to encourage better readiness for the implementation of the minimum competency assessment policy and character survey in 2021. Comprehensive and specific understanding of the various problems faced within the organization is fundamental to encourage schools to make improvements and sustainably improve quality and performance. Practical identification of problems will be used as a reference in efforts to improve, organize and improve so that the implementation of activities can take place more effectively and efficiently and can focus on the essential problems faced.

The low level of understanding of school principals and teachers of the plan for implementing the minimum 
competency assessment policy and character survey gives the impression that the principal and teachers are less proactive in keeping up with new developments and changes in the world of education. This can become an obstacle in the implementation process when the policy is implemented in the coming year. The policy of the Minister of Education and Culture of the Republic of Indonesia, which is planned to impose a minimum competency assessment and survey of workers in schools in 2021 should receive attention and even preparations starting in 2020.

To face the implementation of the minimum competency assessment policy and character survey which is one of the policies which is also a part of the free learning policy, it will provide wider space and autonomy to schools, especially for school principals and teachers to carry out assessments and development of innovative dimensions of the school program. This preparation can take various forms, for example, the stipulation of more specific rules, socialization of policies, indepth discussions at the education and school level and in other forms. From the temporary information that can be gathered, no concrete steps have yet been taken for specific preparation.

Assessment of the minimum competence of students has an important meaning so that learning is not trapped in unbalanced development between cognitive and affective aspects of students, as so far it has received many criticisms from various parties. If studied carefully, the development of learning that pays close attention to the psychological dimensions also has an impact on the development of the cognitive aspects. As research conducted by Basith, Andi and Muhammad (2020), revealed that students' self-confidence has a positive relationship and can even be a predictor of academic achievement.

Assessment of student abilities must indeed include or pay attention to all dimensions of learning. The ability of teachers to use various learning instruments properly and appropriately is an important thing to do, especially if it is associated with dynamic technological developments. The use of good and appropriate learning tools can improve students' cognitive abilities, as the results of research presented by Sari et al. (2020) revealed although there is no significant difference between high-level thinking skills between male and female students, however, learning that is supported by good media devices is proven to be able to strengthen students' high-level thinking skills (HOT), both male and female students.

The problem of the lack of innovative teacher learning models and the lack of ability in the use of technology-based learning media are important dimensions to be considered and corrected. As professionals, reformers and developers in learning activities have a fundamental role in realizing education and learning programs in schools. One of the most important consequences is the task related to the accountability of the learning program. For the sake of schools, having professional teachers is the key to the success of the learning process. If the principal and teachers can optimize their role properly, a positive school culture will be created. School culture provides an overview of the dynamics and state of the school as a whole. Wang and Zepeda (2013: 63) suggested that school culture is one of the attractions of the community or education consumers to use the educational services offered by schools. In this situation, the better or positive the school culture, the better and healthier the learning process will be.

The efforts to develop student character that have been implemented will serve as reinforcement to support the implementation of the character survey launched by the Ministry of National Education in 2021. As it has been implemented so far, the implementation of character education in elementary schools, especially in Sintang district, is carried out through a learning process or outside the process. learning is a step that is appropriate for realizing the expected character dimensions. The results of Ayi's research (2018: 10), found that the real cultivation of character values can be developed through the physics learning process. Likewise, the research results presented by Fauzi, Zainudin, and Rosyid (2018: 83) showed that the inculcation of student character has been proven effective through the development of various learning methods, including discovery learning methods.

Even though it is found that character education has been implemented in every school, schools need to continue to make efforts to find more appropriate ways. It is necessary to study various experiences that have been applied in various places so that it is possible to find more effective ways of developing student character. The results of Wuryandani's research (2016: 208) revealed that among the obstacles to the implementation of character education, especially among others (1) the inconsistency of parents in following school rules to develop student character, (2) on the other hand, schools have not been able to integrate character education comprehensively in the learning process in the classroom. These things should become material for study and motivation to improve the performance that has been achieved so far.

\section{IV.CONCLUSIONS}

Taxonomically, educational problems in supporting the readiness to implement the minimum competency assessment at primary schools in Sintang district can be described educational problems: (a) In the teacher dimension, the main problems faced are the lack of teachers and the lack of equal distribution of placement, low access to opportunities to participate in training programs and lack of mastery of information and communication technology (ICT) in the learning process. Concerning students being faced with problems of lack of learning motivation, weak reading and numeracy literacy, and communication skills. (b) In the dimension of curriculum and learning, it was found that the teacher's level of uncertainty was quite high due to the change in the curriculum at a relatively fast time. In the learning process, students generally tend to expect learning resources from books provided by the school, less trying to explore other learning sources outside which provided by the teacher. (c) In the dimensions of leadership and management of school principals in Sintang District, there are still several school principals who are less assertive and less disciplined, there are still those who are less transparent in terms of fund management and still not optimal in establishing partnerships 
with local agencies and partners. (d) In the dimensions of educational facilities and infrastructure, there are still quite a lot of schools, especially elementary schools which with their limitations carry out learning activities by utilizing rooms that are not less standard in the implementation of the learning process. Likewise, there are still very few learning aids. (e) In the dimensions of community and government participation/support, it is known that real support from the community and/or parents for the implementation and improvement of the learning process is generally still low. Specifically for government involvement, it is still considered a lack of attention to schools that are remote or borderline of Sintang District.

School readiness towards the implementation of minimum competency assessment policies and character surveys in 2021, seen from the readiness for the smooth learning process, coaching student issues, the implementation of coordination by the Education and Culture Ministry, the appropriateness of the character education approach and the activeness of teachers looking for new information is good. Dimensions that are still not optimal, especially in the principal's initiative to encourage teacher involvement in investigating new problems, the lack of speed in discussing if there are new policies or rules and teacher concern for fostering student character. Especially in the dimensions of teacher knowledge about the minimum competency assessment policies and character surveys, it is classified as very low.

\section{REFERENCES}

Afifah, Nurul. (2015). Problema Pendidikan di Indonesia (Telaah Kritis dari Aspek Pembelajaran. Jurnal Elementary, 1(1).

Ayi, Suherman. (2018). The Implementation Of Character Education Values In Integrated Physical Education Subject In Elementary School. Journal SHS Web of Conference. Journal of Social Science. ISSN: 22612424 (Online).

Basith, Abd., Andi Syahputra, Muhammad Aris Ichwanto. (2020). Academic Self-Efficacy as Predictor of Academic Achievement. Jurnal Pendidikan Indonesia: Indonesian of Educational Journal, 9(1).

Fauzi, A., Zainuddin \& Rosyid. (2018). Penguatan Karakter Rasa Ingin Tahu Dan Peduli Sosial Melalui Discovery Learning. Jurnal Teori dan Praksis Pembelajaran IPS, 2(2), 83-93. Issn: 2503-1201, (Print): 2503-5347 (Online).

Maunah, Binti. (2015). Implementasi Pendidikan Karakter dalam Pembentukan Kepribadian Holistik Siswa. Jurnal Pendidikan Karakter, 5(1). ISSN. 2089-5003.

Mc Millan, J.H., Schumacher S. (2001). Research and Education, Fifth Edition A Conceptual Introduction. United Stated: Addision Wesley Longman, Inc.

Mendikbud. (2019). Apa Itu Asesmen Kompetensi Minimum dan Survei Karakter, Diulas Chaterine Rahel Narda. DetikNews. 11 Des 2019.

Mendikbud. (2019). Mengenal Konsep Asesmen Kompetensi Minimum Pengganti Ujian Nasional. https://www.liputan6.com/news/read.
Mendikbud. (2020). AKM dan Implikasinya Pada Pembelajaran. Jakarta: Pusat Asesmen dan Pembelajaran Badan Penelitian dan Pengembangan dan Perbukuan Kementerian Pendidikan dan Kebudayaan.

Nasution, M. Nur. (2015). Manajemen Mutu Terpadu (Total Quality Management). Bogor: Ghalia Indoensia.

Opata, CN., Alfred, S., \& Stephen, T. (2017). The Cultural School of Strategic Formulation (Strategy Formulation Based on Social Interactions, Beliefs and Traditions). DOI: 10.4236/ojbm.2017.52029, 335-347.

Pemerintah Kabupaten Sintang. (2016). Rencana Pembangunan Jangka Menengah Daerah (RPJMD). Pemda Kabuaten Sintang.

Sari, Endah, et al. (2020). Are Male and Female Students Different in High-order Thinking Skills? Jurnal Pendidikan Indonesia: Indonesian of Educational Journal), 9(1).

Wang, F. \& Zepeda, S. (2013). A Comparative Study of Two Schools: How School Cultures Interplay the Development of Teacher Leadership in Mainland China. Creative Education Journal, 4, 63-68. DOI: 10.4236/ ce.2013.49B013.

Widodo, Heri. (2015). Potret Pendidikan Di Indonesia Dan Kesiapannya Dalam Menghadapi Masyarakat Ekonomi Asia (MEA). Jurnal Cendekia, 13(2), 295.

Wuryandani, W., Faturrohman, Unik A. (2016). Implementasi Pendidikan Karakter Kemandirian di Muhammadiyah Boarding School. Cakrawala Pendidikan: Jurnal Ilmiah Pendidikan, 35(2).

Yanuar, Yudono. eds (2019). Inilah Asesmen Kompetensi Minimum Pengganti Ujian Nasional. https://tekno.tempo.co/read/1284119. 